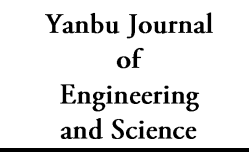

ISSN: 1658-5321
Vol. 13, December $2016(1438 \mathrm{H})$ www.yjes.org.sa

\title{
DECENTRALIZED TREATMENT OF HARVESTED RAINWATER FROM ROOFTOPS IN BURAIDAH CITY, SAUDI ARABIA
}

\author{
Yousry Ghazaw ${ }^{1}$, Tarek Elmitwalli ${ }^{2}$, Abdul Razzaq Ghumman ${ }^{3}$ \\ ${ }^{1,2,3}$ Department Civil Engineering, College of Engineering, Qassim University, Buraidah, Kingdom of Saudi Arabia \\ ${ }^{1}$ On leave from Alexandria Univ., Egypt \\ Email: ghazaw@qec.edu.sa
}

\begin{abstract}
Water scarcity is one of the most sensitive issues of this century. Several countries are posed with the same problem of water scarcity in the Kingdom of Saudi Arabia (KSA). Thus, an optimal use of various water resources, including rainwater, is extremely crucial. However, the quality of water needs to be assessed before any usage. The present study investigated the quality of rainwater in the Qassim region of KSA. The building of Civil Engineering Department, College of Engineering, Qassim University, Buraidah was selected as the experimental site. The rainwater from the roof of the department was periodically collected in from October 2011 to July 2012. The harvested rainwater was assessed for the quality and accordingly treated physically and chemically. First, the collected water was pumped onto a filter paper column, type POSI-FLO $^{\circ}$ II, to remove the large particles. Subsequently, four cartridge filters with different filter media, followed by reverse osmosis unit, were used for the treatment. The experimental results demonstrated that the characteristics of the harvested and treated rainwater from the rooftops of building in Buraidah could be used for drinking.
\end{abstract}

Keywords: Rainwater, physical treatment, chemical treatment, filtration, reverse osmosis.

\section{INTRODUCTION}

Water resources planning, development, and management is a topic of intensive research currently. Water resources in the Kingdom of Saudi Arabia (KSA) are limited and require serious efforts for optimal usage. Urban development, high rate of population growth, aridity, high solar radiation, and increasing water demand are stressful on the existing water resources. The Al-Qassim Region, wellestablished for agriculture, experiences more pressure in this sector as compared to the other areas of KSA since most of the water resources are non-renewable. Therefore, a profound strategy is essential to harvest the rainfall in arid regions. The engineering and management of water resources are being persistently investigated worldwide. Several aspects including management, conservation, and efficient use of water for drinking, industry, and irrigation have been studied in the recent years with an emphasis on rainwater harvesting (RWH) [1-6]. Several methods have been proposed to increase the sources of water supply worldwide; RWH is considered a feasible alternative source [7-10]. Recently, RWH has gained enormous attention in KSA [11-12]. The method can also significantly improve water saving in other countries. For example, Herrmann and Schmida [13] showed that in Germany, the potential of potable water saving by RWH in 
a house might vary from $30-60 \%$, which is demand- and roof area-dependent. Coombes and Kuczera [14] analyzed 27 houses in Australia and found that rainwater usage could promote the potable water saving up to $60 \%$. Ghisi et al. [15] indicated that the potential water saving by RWH in 62 cities in Brazil was 34-92\%, with an average of $69 \%$ potable water saving. Several other studies have highlighted the various aspects of RWH [16-17]. Adham et al. [18] conducted investigations to identify various sites for RWH. The study proposed that although the site selection is challenging, RWH might provide an alternative water source in semiarid or arid countries. The group highlighted the key methods and criteria developed during the past three decades based on 48 studies describing diverse methods. Some of these methods were designed according to simple biophysical criteria, whereas others were more integrated approaches including socio-economic criteria. The most significant criteria for selecting the suitable sites encompass land use, slope, land cover, soil type, the amount of rainfall, distance to any reservoir, and the cost, which altogether can culminate in a successful RWH project. In addition, the practice of geographic information systems (GIS) combined with hydrological models and the criteria mentioned above may also be highly useful. The quality of the harvested rainwater is mostly low [19] that can be attributed to atmospheric pollutants including particles, microorganisms, heavy metals, and organic substances accumulating in the catchment areas as dry deposition and washouts from the atmosphere during rainfall events. The measured inorganic compounds in the rainwater harvested from most of the roofyard catchment systems were found to be consistent with those of the World Health
Organization (WHO) standards for drinking water. However, the concentrations of some inorganic compounds in the rainwater collected from the road surfaces appeared to be higher than the guideline values for drinking water. In the case where the catchment areas are roads, the rainwater may be contaminated with heavy metals originating from brakes and tires and organic compounds such as polycyclic aromatic hydrocarbons and aliphatic hydrocarbons from incomplete combustion processes. The contaminants comprising of bacteria, viruses, and protozoa may originate from pollution by birds, mammals, and reptiles that have access to catchments and rainwater storage tanks. Therefore, the harvested rainwater is typically unsuitable for drinking without some treatment [20], which should be practical and cost-effective in developing countries. The removal of pollutants from rainwater by filtration techniques is a common practice. Suspended solids (SS) may be removed by filtration. Activated carbon removes organic compounds that contribute to taste and odor [20]. However, the pore space between the sand particles is larger than the smallest suspended particles, rendering simple filtration as insufficient in most cases. For drinking water, the membrane filter systems can effectively remove protozoa, bacteria, algae, and other microorganisms depending on the pore size of the membrane. Nevertheless, the treated water may still contain some viruses, because their dimensions $<100 \mathrm{~nm}$ allow easy slippage even through minuscule pores. Therefore, the filter systems are coupled with a disinfection system [19]. The present study primarily aims to (1) evaluate the potential physical and chemical processes in the treatment of the harvested rainwater, (2) study the membrane filtration and $\mathrm{RO}$ in the treatment of the harvested 
rainwater, and (3) provide suggestions and recommendations regarding the improvement of the quality and quantity of the harvested rainwater in KSA.

\section{STUDY AREA}

Figure. 1(a) shows the location map of the study area. Figure. 1(b) shows the building that was used for RWH. The area of the rooftop of the building was approximately $960 \mathrm{~m}^{2}$ and height $4.5 \mathrm{~m}$. Qassim is a wellestablished agricultural region in Saudi Arabia, also known for dates. The experimental site was located in the Qassim University Campus in Miladah near Prince Nayef bin Abdulaziz Regional Airport. The coordinates of the study area were: Latitude Longitude $26^{\circ} 20^{\prime}$

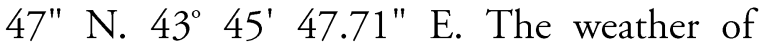
Qassim is almost similar to that of Riyadh, the capital of the KSA. The average annual rainfall is approximately $140 \mathrm{~mm} /$ year. The highest and lowest temperatures are $50{ }^{\circ} \mathrm{C}$ in summer and $0{ }^{\circ} \mathrm{C}$ in winter, respectively.

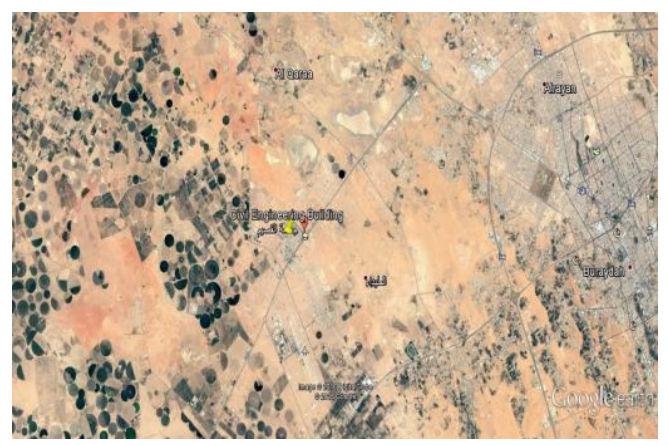

Fig. 1(a). Location map of the study area

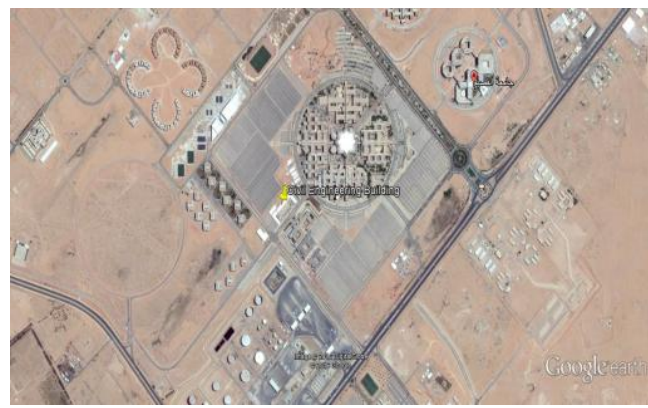

Fig. 1(b). Building used as the experimental site for rainfall harvesting

\section{MATERIALS AND METHODS}

The quality of the drinking water complied with the standards of SAS in KSA. A comparison between the quality of the existing bottled drinking water used in KSA and that achieved by WHO and SAS is summarized in Table $1[21,22,23]$.

TABLE 1: EXISTING BOTTLED DRINKING WATER QUALITY IN KSA AND QUALITY STANDARDS $[21,22,23]$

\begin{tabular}{|c|c|c|c|c|}
\hline Constituent & Units & SAS & WHO & $\begin{array}{c}\text { Existing } \\
\text { water } \\
\text { quality in } \\
\text { KSA }\end{array}$ \\
\hline $\mathrm{P}^{\mathrm{H}}$ & - & $\begin{array}{c}6.5- \\
8.5\end{array}$ & $6.0-8.5$ & 7.18 \\
\hline TDS & $\mathrm{MG} / \mathrm{L}$ & 1500 & 1000 & 226.5 \\
\hline TURBIDITY & NTU & 25.0 & 5.0 & - \\
\hline CALCIUM (Ca) & $\mathrm{MG} / \mathrm{L}$ & 200 & 200 & 36.6 \\
\hline MAGNESIUM (Mg) & $\mathrm{MG} / \mathrm{L}$ & $\begin{array}{l}30- \\
150\end{array}$ & 100 & 14.1 \\
\hline TOTAL HARDNESS & $\mathrm{MG} / \mathrm{L}$ & 500 & 500 & 168 \\
\hline MANGANESE (Mn) & $\mathrm{MG} / \mathrm{L}$ & 0.05 & 0.1 & - \\
\hline IRON (Fe) & $\mathrm{MG} / \mathrm{L}$ & 1.0 & 0.3 & - \\
\hline CHLORIDE (Cl) & $\mathrm{MG} / \mathrm{L}$ & 600 & 250 & - \\
\hline FLUORIDE (F) & $\mathrm{MG} / \mathrm{L}$ & $\begin{array}{c}0.6- \\
1.0\end{array}$ & $0.6-1.7$ & 0.81 \\
\hline COLIFORM & $\begin{array}{c}\text { NO./100 } \\
\text { ML }\end{array}$ & 0 & 0 & 0 \\
\hline FECAL COLIFORM & $\begin{array}{c}\text { NO./100 } \\
\text { ML }\end{array}$ & 0 & 0 & 0 \\
\hline \multicolumn{5}{|c|}{$\begin{array}{r}S A S=\text { SAUDI ARABIA STANDARD } \\
W H O=W O R L D \text { HEALTH ORGANIZATI } \\
K S A=\text { KINGDOM OF SAUDI ARABIA }\end{array}$} \\
\hline
\end{tabular}




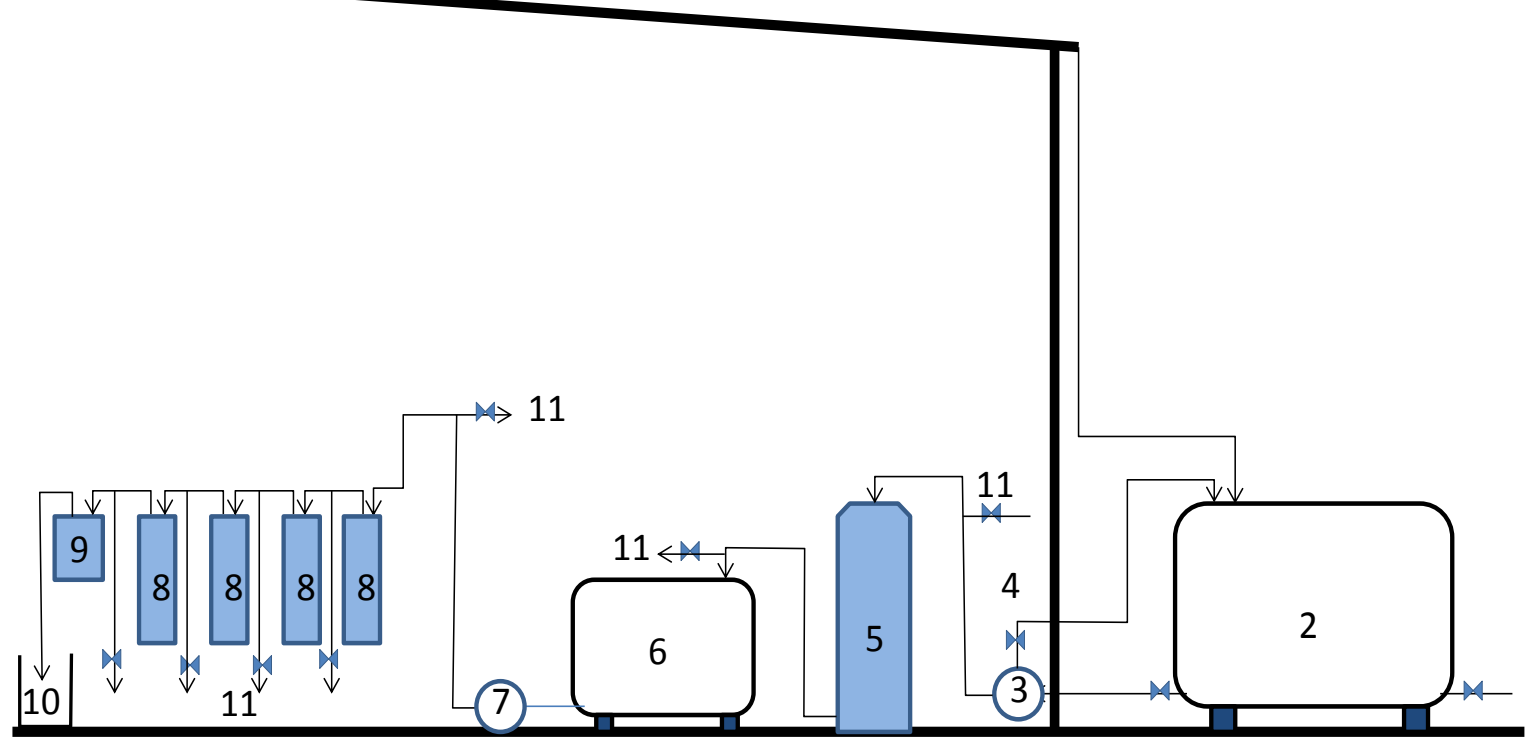

Fig. 2. Schematic representation of the rainwater harvesting (RWH) and treating system. 1: roof; $2: 1 \mathrm{~m}^{3}$ storage tank; 3: pump; 4: valve for water recirculation; 5: paper-filter column; 6: $0.3 \mathrm{~m}^{3}$ water storage tank; 7: pump; 8: cartridge filters; 9: reverse osmosis (RO) unit; 10: container for treated water; 11: sampling valve.

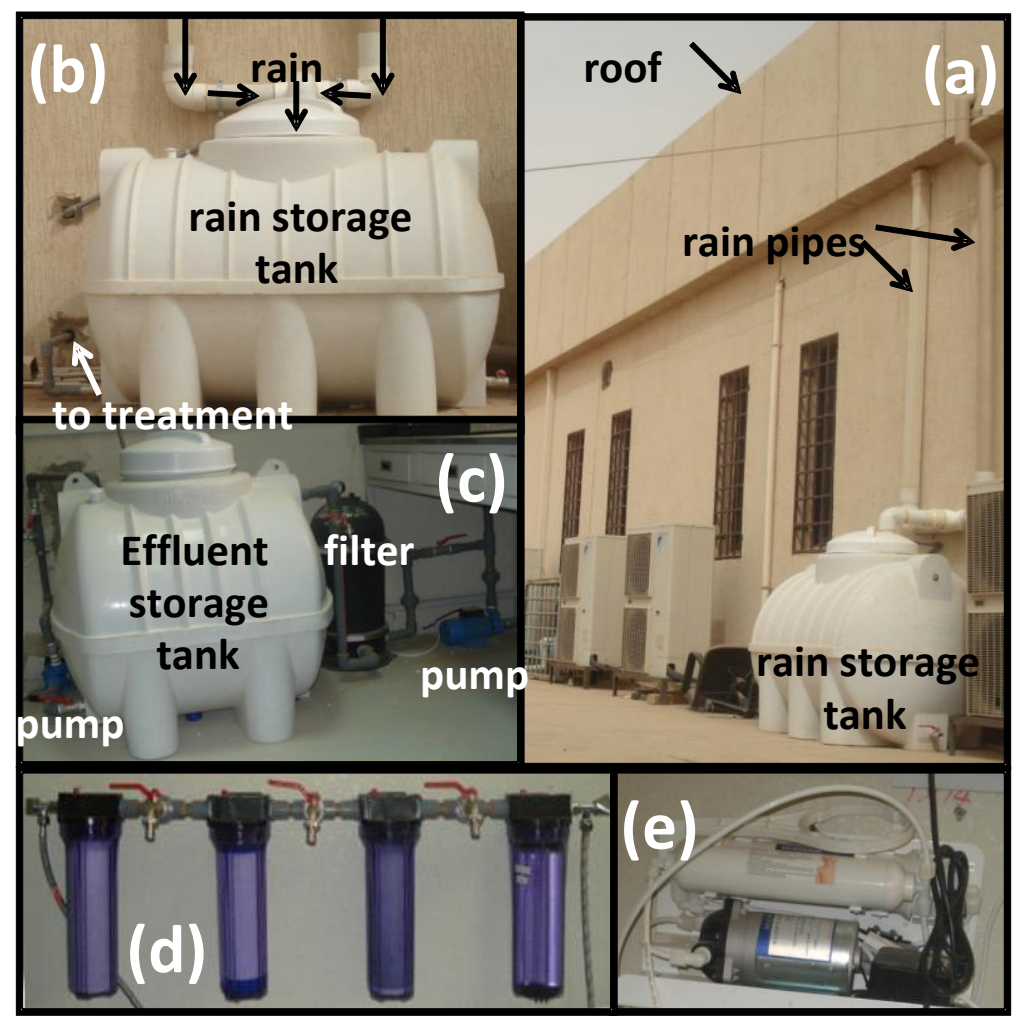

Fig. 3. Images of the experimental set-up. (a): rainwater collection system; (b): rainwater storage tank; (c): filter-paper column and pre-treatment step; (d): cartridge filters; (e): RO unit. 
Figure 2. illustrates a schematic representation of the system for harvesting and treating the rainwater. The rainwater was harvested from the roof of the building of Civil Engineering Department, Qassim University and stored in a $1 \mathrm{~m}^{3}$ tank as shown in Figure 3(a) and 3(b), respectively. Subsequently, the water was pumped to a filter paper column, type POSIFLO $^{\circ}$ II as demonstrated in Figure 3(c) for the removal of large particles. The height and diameter of the filter paper column were 102 and $41 \mathrm{~cm}$, respectively, and the effective area of the filter paper was $4.6 \mathrm{~m}^{2}$. The pre-treated water was collected in a $0.3 \mathrm{~m}^{3}$ tank [Figure $3(\mathrm{c})$ ], and then, pumped to the four cartridge filters as in Figure 3(d) with different filter media, followed by transfer to the RO unit [Figure 3(e)]. The media used in the four cartridge filters comprised of nylon, granular activated carbon (pore size $=10 \mu \mathrm{m}$ ), granular activated carbon (pore size $=5 \mu \mathrm{m}$ ), and powder activated carbon, sequentially. The diameter and height of each cartridge were 10 and $25 \mathrm{~cm}$, respectively. The system was operated to treat either raw or settled rainwater. In order to prevent the raw water from settling, a part of it was recirculated to the $1 \mathrm{~m}^{3}$ storage tank. On the other hand, to operate the system with settled rainwater, the SS of raw water were allowed to settle in the storage tank by 1 -day retention. At every condition, the filter paper column treated the water at two different flow rates (10 and 20 $\mathrm{L} / \mathrm{min}$, respectively). The stored effluent obtained from the filter paper column was treated by the four cartridge filters at a flow rate of $1 \mathrm{~L} / \mathrm{min}$, followed by the RO unit, which has flow rates of 0.75 and $0.25 \mathrm{~L} / \mathrm{min}$ for permeation and rejection, respectively. The physical and chemical treatments of the harvested rainwater were evaluated by jar tests. In this method, two coagulants were utilized, alum and cationic polyacrylamide polymer.
The jar tests were performed at different doses. The durations of rapid mixing, flocculation, and sedimentation in the jar tests were 1,20 , and $30 \mathrm{~min}$, respectively.

\section{RESULTS AND DISCUSSION}

\subsection{Characteristics OF THE HaRVESTED RAINWATER}

The rainwater was collected and treated from October 2011 to July 2012. Figure 4 presents the average monthly rain precipitation from 2005 to 2012 in the Qassim Province [24]. Figure 5 presents some events of rainfall in the Qassim region, which exceeds 5 $\mathrm{mm}$ /event during the past ten years (20072016). The average annual precipitation from 2005 to 2012 was $95.9 \mathrm{~mm}$, indicating that the precipitation was relatively low.

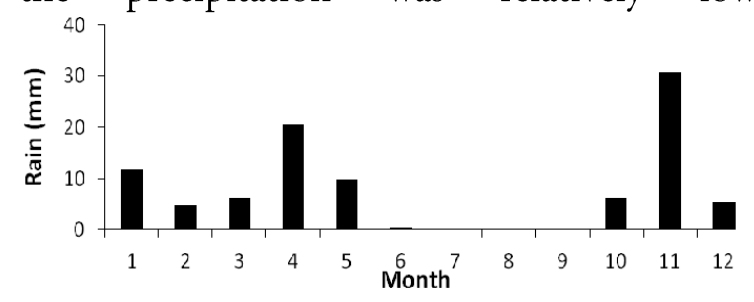

Fig. 4. Mean precipitation in Qassim Province from 2005 to 2012

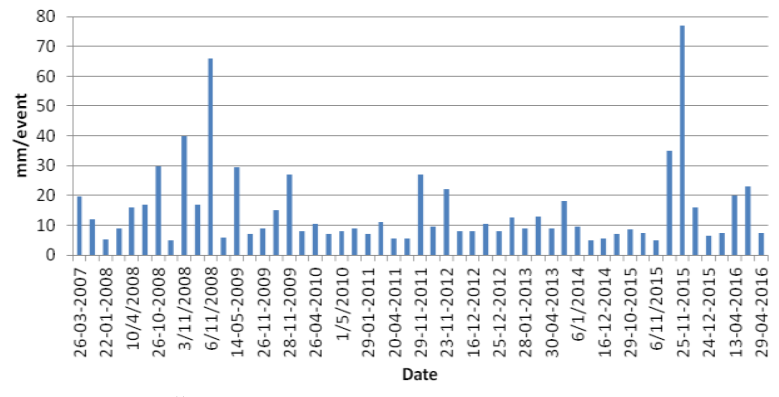

Fig. 5 Rainfall in Qassim region, Saudi Arabia which exceeds 5 mm/event (2006-2016)

Table 2 shows the characteristics of the harvested rainwater. The data on the quality of rainwater of some previous events are described in Table 3 [25] and can be compared with the current results. Some of the reference values were found in agreement with the present study, while a few varied; for instance, the $\mathrm{pH}$ values corroborated, conductivity was about half of the present results, and TDS (total dissolved solids), 
alkalinity, and hardness were higher in the present study than the previous results. Furthermore, the harvested rainwater exhibited a relatively high concentration of SS as compared to that reported by results of previous studies performed in other places. This phenomenon may be attributed to the sandy weather and the harvest of the rainwater without excluding the first flush. Thus, the collected rainwater presented an optimum $\mathrm{pH}$, a significant amount of SS and TDS, and sufficient alkalinity. It also exhibited low concentrations of the other compounds (nitrate, nitrite, ammonium, sodium, and copper). Therefore, the removal of SS by disinfection can produce treated rainwater with drinking water quality.
TABLE 2: CHARACTERISTICS OF THE HARVESTED RAINWATER (EVENTS NOV-2011)

\begin{tabular}{|c|c|c|}
\hline Parameter & Unit & Value \\
\hline SS & $\mathrm{mg} / \mathrm{L}$ & 15 \\
\hline Turbidity & $\mathrm{NTU}$ & 24 \\
\hline $\mathrm{TDS}$ & $\mathrm{mg} / \mathrm{L}$ & 262 \\
\hline Conductivity & $\mathrm{mS}$ & 0.67 \\
\hline Sodium & $\mathrm{mg} / \mathrm{L}$ & 3 \\
\hline Iron & $\mathrm{mg} / \mathrm{L}$ & 0.03 \\
\hline $\mathrm{NO}_{3}-\mathrm{N}$ & $\mathrm{mg} / \mathrm{L}$ & 5 \\
\hline $\mathrm{NO}_{2}-\mathrm{N}$ & $\mathrm{mg} / \mathrm{L}$ & 0 \\
\hline $\mathrm{NH}_{4}-\mathrm{N}$ & $\mathrm{mg} / \mathrm{L}$ & 0.5 \\
\hline $\mathrm{Coppper}_{\text {Hardness }}$ & $\mathrm{mg} / \mathrm{L}$ & 0 \\
\hline Alkalinity & $\mathrm{mg} / \mathrm{L}$ & 175 \\
\hline $\mathrm{pH}$ & - & 120 \\
\hline
\end{tabular}

TABLE 3: RAINWATER ANALYSIS OF SOME PAST EVENTS [25]

\begin{tabular}{|c|c|c|c|c|c|c|c|c|}
\hline $\begin{array}{c}\text { COLLECTION } \\
\text { DATE }\end{array}$ & SAMPLE NO & $\mathrm{pH}$ & $\begin{array}{c}\text { COND } \\
(\mathbf{m s} / \mathbf{c m})\end{array}$ & TDS & ALKALINITY & HARDNESS & SODIUM & NO 3 \\
\hline $03-1994$ & 1 & 7.41 & 0.3 & 146 & 70 & 0.17 \\
\hline $04-1994$ & 2 & 7.73 & 0.28 & 158 & 105 & 132.4 & 3.62 \\
\hline $04-1994$ & 3 & 7.85 & 0.29 & 114 & 76 & 75.7 & 0.17 \\
\hline
\end{tabular}

Figure 6 demonstrates that high turbidity removal can be achieved by coagulants, alum or polymer, at a high dose. Moreover, the amount of particles in the harvested rainwater was comparatively lower, as a low dose of coagulant was applied for the removal of turbidity in the surface water. The results of the jar test revealed low turbidity in the treated rainwater, which is lower than that of the drinking water. Plain sedimentation of the harvested rainwater for one day in the storage tank results in a significant reduction of the raw water turbidity. Therefore, treating the rain water with coagulant is significantly better than plain sedimentation.

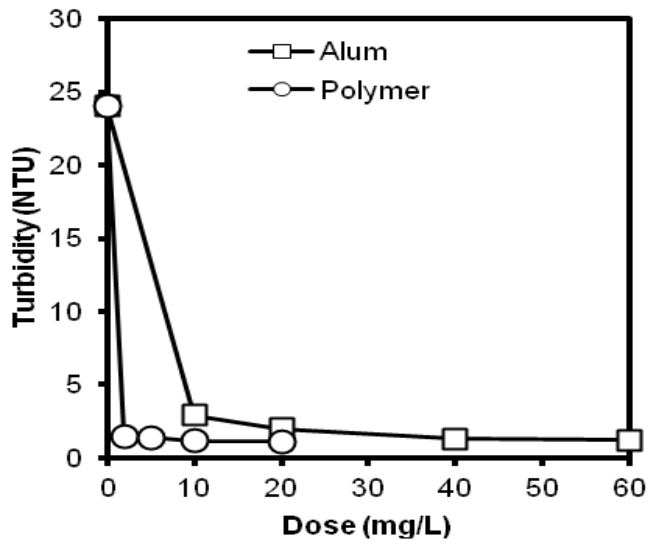

Fig. 6. Jar test results showing the effect of alum and polymer in turbidity removal at different coagulant doses at 1 min mixing time

Figure 7 demonstrates the results of the rainwater (raw or settled) treatment in the filter paper column. 

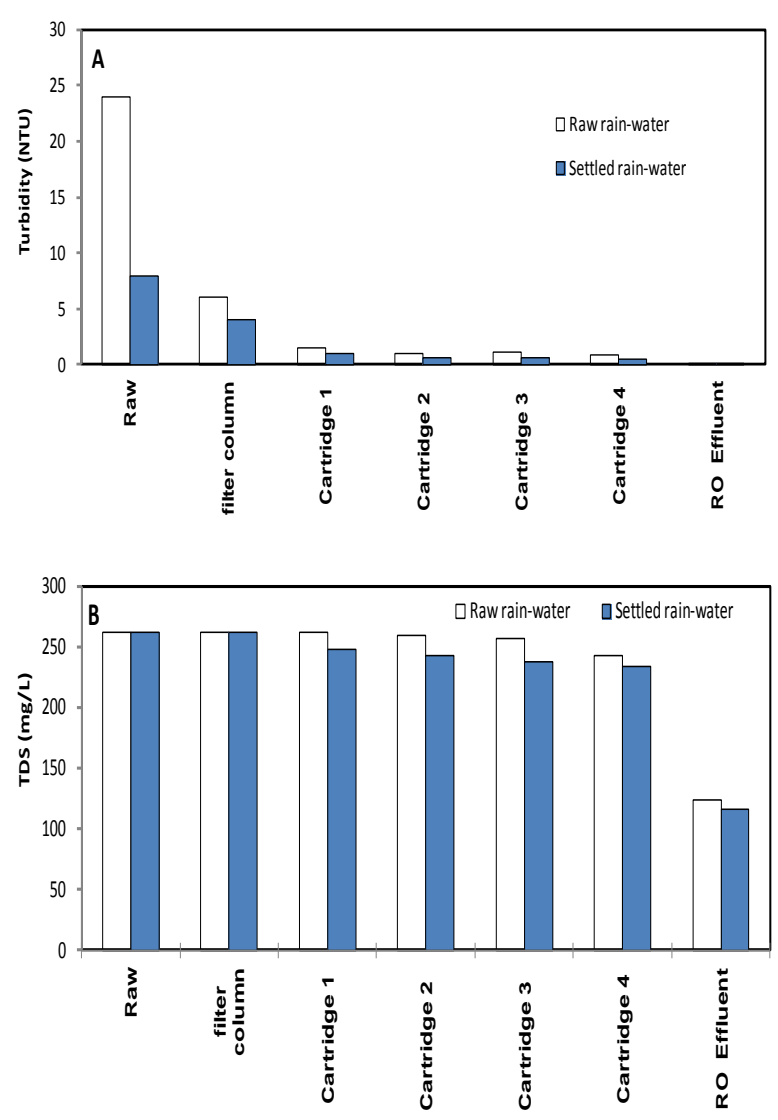

Fig. 7. Results of continuous treatment of the rain water

A minimum of two stages of cartridge filters are required for obtaining an effluent with characteristics similar to that of the drinking water (turbidity $<1 \mathrm{NTU}$ ). Moreover, the results also emphasize the importance of sedimentation as a pre-treatment of the rainwater. The rainwater has a TDS of 262 $\mathrm{mg} / \mathrm{L}$, which is lower than that required for water supply in KSA $(500 \mathrm{mg} / \mathrm{L})$. In addition, applying $\mathrm{RO}$ can achieve a significant reduction in TDS depending on the operational conditions. Figure 7 also demonstrates that the filter column has no effect on TDS; however, cartridges 1, 2, 3, and 4 and RO reduce the TDS from 262 to $250 \mathrm{mg} / \mathrm{L}, 250$ to $247 \mathrm{mg} / \mathrm{L}, 247$ to 244 $\mathrm{mg} / \mathrm{L}, 244$ to $240 \mathrm{mg} / \mathrm{L}$, and 240 to 120 $\mathrm{mg} / \mathrm{L}$, respectively. Since KSA continually experiences water scarcity; the utilization of the harvested rainwater needs to be optimized. The experimental results demonstrate that the characteristics of the harvested rainwater from the roof of the College of Engineering building, Qassim University, are superior to that of the surface water. The settling of the harvested rainwater leads to a significant reduction in SS that can increase the performance of the subsequent steps. The filter column can remove the fine particles that were not removed by settling, making it optimal for irrigation. For turbidity $<1$ NTU, two cartridge filters (textile and coal) are required to treat the effluent of the filter column; however, this water is suitable in the house only for toilet flushing and clothes washing. Furthermore, an additional RO step is essential to obtain drinking water. Fig. 8 summarizes the different proposed steps for treatment of the harvested rainwater and the reuse of the treated water. The proposed systems for the treatment and reuse of harvested rainwater can be applied in small communities (separate houses or buildings).

\section{SUMMARY AND CONCLUSIONS}

The experimental results concluded that the characteristics of the harvested rain from the roof of a building in Buraidah are superior to that of the surface water. The settling of the harvested rainwater leads to a significant reduction in SS, which in turn increases the performance of the subsequent steps in the treatment. The water treated by filter column can be used for irrigation or swimming pools. A turbidity of $<1$ NTU can be obtained by subjecting the effluent of the column to two cartridge filters (textile and coal). Then, the treated water can be utilized for secondary purposes, such as toilet flushing and clothes washing. Drinking water is obtained by an additional RO step. The jar test results concluded that the high turbidity could be removed by coagulants. Alum represents a cost-effective coagulant producing a large 
amount of inorganic sludge, while the polymer represents an expensive coagulant producing a low amount of sludge. Thus, coagulation and sedimentation can be applied to the treatment of a large volume of rainwater in a small area. The present study affirmed the quality of rooftop harvested rainwater as appropriate. Depending on the local environmental conditions, RWH may provide a supplementary supply, an alternative supply, or the only feasible, improved supply, especially in urban areas. In order to meet these challenges, it is recommended that the Government of KSA implement the rooftop RWH mandatory for all buildings. RWH primarily consists of collection, storage, and subsequent use of the captured rainwater as either the principal or as a supplementary source of water. Both potable and non-potable applications are recommended. However, further studies to investigate simple treatment techniques are essential.

\section{ACKNOWLEDGMENTS}

The authors would like to acknowledge the Deanship of Scientific Research in Qassim University, KSA for the financial support for this research (Grant number: 694). The authors would also like to thank the Dean, College of Engineering, Chairman Civil Engineering Department, and other colleagues from the college providing moral support for the successful completion of this project.

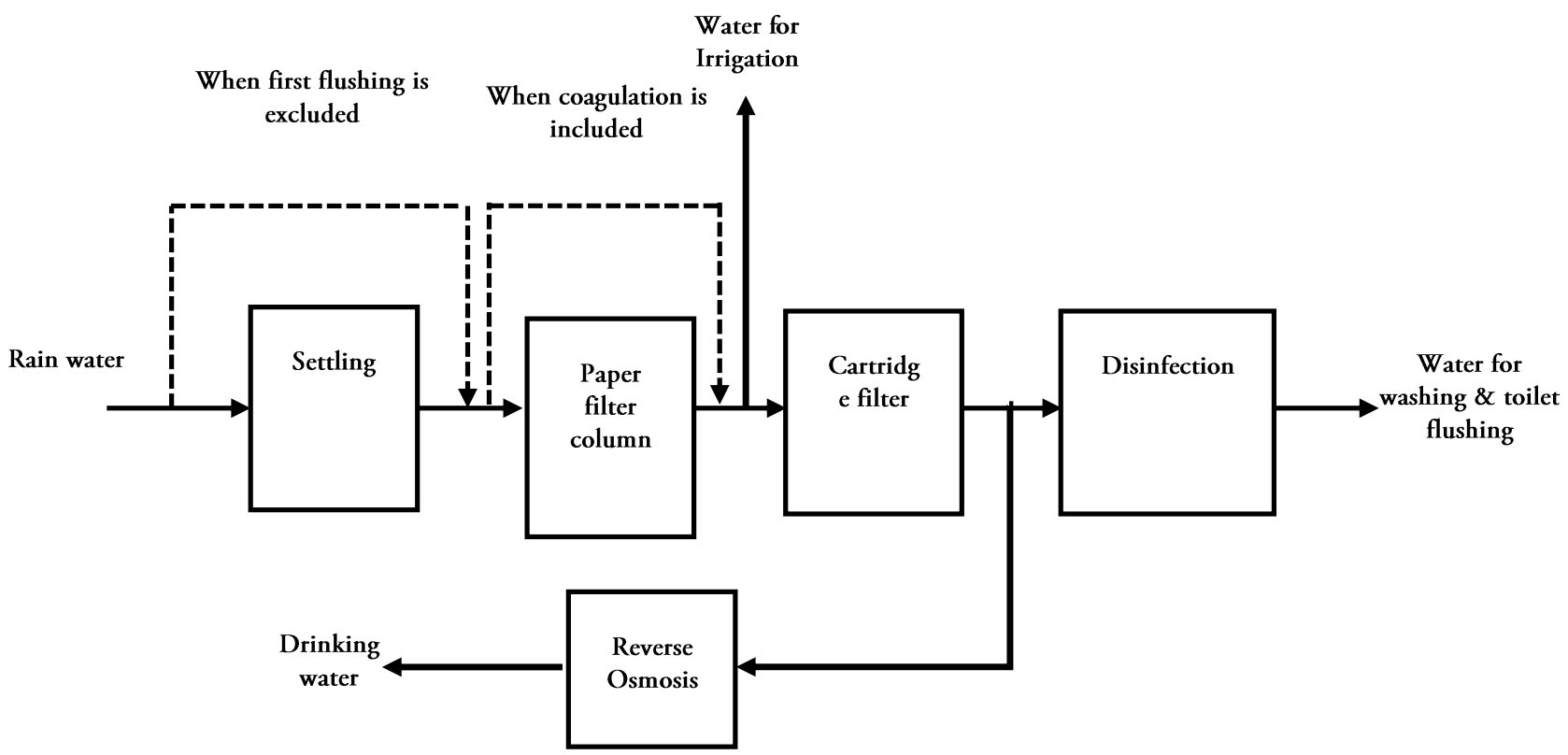

Fig. 8. Proposed treatment steps for harvested rainwater and the reuse of the treated water 


\section{REFERENCES}

[1] Adham A., Riksen M., Ouessar M. and Ritsema C. J. 2016, A Methodology to Assess and Evaluate Rainwater Harvesting Techniques in (Semi-) Arid Regions. Water, Vol. 8, 198; pp 123.

[2] Amos C. C., Rahman A. and Gathenya J. M. 2016, Economic Analysis and Feasibility of Rainwater Harvesting Systems in Urban and PeriUrban Environments: A Review of the Global Situation with a Special Focus on Australia and Kenya, Water, Vol 8, Issue 149, pp 1-21.

[3] Matos, C.; Bentes, I.; Santos, C.; Imteaz, M.; Pereira, S. 2015, Economic analysis of a rainwater harvesting system in a commercial building. Water Resour. Manag. Vol. 29, pp 3971-3986.

[4] Mahmoud, S.H.; Alazba, A.A. 2014, The potential of in situ rainwater harvesting in arid regions: Developing a methodology to identify suitable areas using GIS-based decision support system. Arab. J. Geosci. Vol. 72, pp 3429-3442.

[5] Ursino N., 2016, Risk Analysis Approach to Rainwater Harvesting Systems, Water, Vol , 8, 337, pp 1-8.

[6] Kuller, M., Dolman, N., Vreeburg, J., \& Spiller, M. 2015. Scenario analysis of rainwater harvesting and use on a large scale-assessment of runoff, storage and economic performance for the case study Amsterdam Airport Schiphol. Urban Water Journal, 1-10.

[7] Ziaul Islam K, Sirajul Islam M, Jean OL, Lisa D, 2014 Low cost rainwater harvesting: an alternate solution to salinity affected coastal Region of Bangladesh. Am J Water Resour 2(6):141-148

[8] Zhang X, Hu M, 2014. Effectiveness of rainwater harvesting in runoff volume reduction in a planned industrial park, China. Water Resour Manag 28:671-682

[9] Abu Zreig M, Hazaymeh A, 2012. Evaluation of residential rainfall harvesting systems in Jordan. Urban Water J 1-7

[10] Al-Salaymeh A, Al-Khatib IA, Arafat HA, 2011, Towards sustainable water quality: management of rainwater harvesting cisterns in Southern Palestine. Water Resour Manag 25:1721-1736

[11] Chowdhury S.; Al-Zahrani M. 2015, Characterizing water resources and trends of sector. wise water consumptions in Saudi Arabia,
Journal of King Saud University - Engineering Sciences 27, 68-82.

[12] Guizani M. 2016, Storm Water Harvesting in Saudi Arabia: a Multipurpose Water Management Alternative, Water Resour Manage vol 30 pp 1819-1833.

[13] Herrmann T. and Schmida U. 2000, Rainwater Utilisation in Germany: Efficiency, Dimensioning, Hydraulic and Environmental Aspects, Journal of Urban Water 1(4):307-316.

[14] Coombes P. J.; and Kuczera G., 2003, Analysis of the Performance of Rainwater Tanks in Australian Capital Cities, 28th International Hydrology and Water Resources Symposium: About Water; Symposium Proceedings. Barton, A.C.T.: Institution of Engineers, Australia, 2003: 2.235-2.242.

[15] Ghisi, D.L. Bressan, M. Martini, 2007, Rainwater tank capacity and potential for potable water savings by using rainwater in the residential sector of southeastern Brazil, Building and Environment, 42 (4) (2007), pp. 1654-1666.

[16] Mathur M. 2014, Modelling RainwaterHarvesting System Reliability Based on Historical Precipitation Data for Portland, Civil and Environmental Engineering Master's Project Reports. Paper 11, Portland State University.

[17] Liaw C. H.and Chiang Y. C., 2014, Framework for Assessing the Rainwater Harvesting Potential of Residential Buildings at a National Level as an Alternative Water Resource for Domestic Water Supply in Taiwan, Water 2014, 6, 3224-3246.

[18] Adham A., Riksen M., Ouessar M. and Ritsema C. J. 2016, Identification of suitable sites for rainwater harvesting structures in arid and semiarid regions: A review. International Soil and Water Conservation Research Vol. 4, pp108-120.

[19] Rahman S., Khan M. T. R., Akib S., Che Din C., Biswas S. K., and Shirazi S. M., 2014, Sustainability of Rainwater Harvesting System in terms of Water Quality, The Scientific World Journal, Volume 2014. pp 1-10

[20] Mendez C. B., Brigit R., KinneyA. K., Barrett M. E, Kirisits M. J, 2010 Effect of Roof Material on Water Quality for Rainwater Harvesting Systems, Texas Water Development Board P.O. Box 13231, Capitol Station Austin, Texas 787113231.

[21] WHO, World Health Organization, Guidelines for Drinking Water Quality. 2nd ed. Health 
Criteria and Other Supporting Information. Vol. 2 WHO, Geneva, Switzerland, 1996.

[22] Royal Commission Environmental Regulations, Saudi Arabia, RCER-2015, Volume I, Regulations and Standards, pp 51-72, 2015

[23] Ashraf E.M. Khater, Asma Al-Jaloud and A. ElTaher, 2014, Quality Level of Bottled Drinking Water Consumed in Saudi Arabia. Journal of Environmental Science and Technology, Vol 7: pp 90-106.
[24] Ghazaw Y. M., 2009, Harvesting runoff from rainfall for groundwater recharge in Saudi Arabia, The International Conference on Water Conservations in Arid Regions 12-14 Oct-2009, Jeddah Saudi Arabia.

[25] Alabdula'aly, A. I. and Khan, M. A., 2000: Chemistry of rain water in Riyadh, Saudi Arabia. Archives of Environmental Contamination and Toxicology 39(1): 66-73. 
دراسة ومعالجة مياه الأمطار المجمعة من أسطح المباني في مدينة بريدة، المملكة العربية السعودية

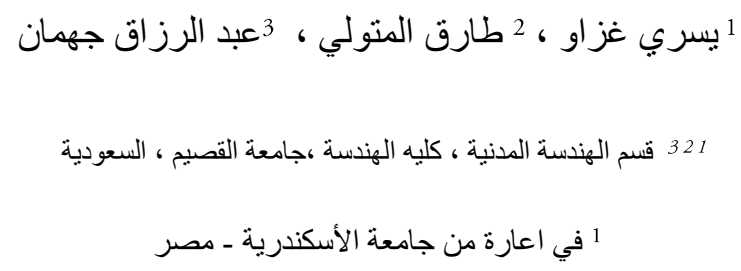

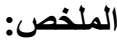

ندرة المياه هي واحدة من أكثر القضايا حساسية في القرن 21. المملكة العربية السعودية مثل العديد من البلدان الأخرى و التي تو اجه مشكلة ندرة المياه. الاستخدام الأمثل للموارد المائية المختلفة بما في ذلك مياه الأمطار مهم للغاية. لا بد من التحقق من نوعية المياه قبل أي استخدام. في هذه الدراسة تم التحقق من جودة مياه الأمطار في منطقة القصيم في المملكة العربية السعودية. تم جمع البيانات من خلال التجارب الحقلية والمعلية. تم اختيار قسم الهندسة المدنية، كلية الهنسة -جامعة القصيم بريدة كموقع تجريبي. تم جمع مياه الأمطار من سطح قسم الهندسة المدنية في خزان خلال الفترة من أكتوبر 2011 إلى يوليو 2012. تمت معالجة مباه الامطار بطرق فيزيائية وكيميائية. نم اختبار عينات من مياه الأمطار في المختبر لمعرفة نوعيتها ونم التعامل معها وفقا لذلك. وكخطوة أولى نم ضخ المياه التي نم جمعها إلى عمود مرشح والذي كان يستعمل في إزالة الجزيئات الكبيرة و وقد استخدمت لذلك أربع مرشحات تتبعها وحدة التتاضح العكسي لإتمام المعالجة. اظهرت النتائج التجريبية أن خصائص مياه الأمطار من اسقف المباني في بريدة يمكن استخدامها للشرب بعد المعالجة المقترحة. 